\title{
KEJAHATAN-KEJAHATAN INTERNASIONAL (TINDAK PIDANA INTERNASIONAL) DAN PERANAN INTERNATIONAL CRIMINAL COURT (ICC) DALAM PENEGAKAN HUKUM PIDANA INTERNATIONAL
}

Oleh :

\author{
Indah Sari, SH, M.Si
}

(Email : Indah.alrif@gmail.com)

Dosen Tetap Fakultas Hukum Universitas Suryadarma dan Aktif di Lembaga Konsultasi Bantuan Hukum

(LKBH) Fakultas Hukum Universitas Suryadarma serta anggota Asosiasi Dosen Seluruh Indonesia (ADI)

\begin{abstract}
:
International criminal law is "the law which determines what national criminal law will apply to offences actually committed if they contain an international element". Beside that, the definition of international criminal law in the meaning of the territorial scope of municipal criminal law, the meaning of internationally prescribed municipal criminal law, in the meaning of municipal criminal law common to civilized nations, in the meaning of international co-operation in the administration of municipal criminal justice

An international crimes is such an act universally recognized as a criminal which is considered a grave matter of international concern and for some valid reason cannot be left within the exclusive jurisdiction of the state, that would have control over it under normal circumstances.

In the context of international criminal law, the International Criminal Court is a permanent court formed by the United Nations based on Statute of Rome 1998. The Court designated as an instrument to prosecute people who commit any international crimes.
\end{abstract}




\section{PENDAHULUAN}

Pertumbuhan dan perkembangan Tindak Pidana Internasional dan kebutuhannya pengaturannya diawali oleh sejarah panjang mengenai perang yang telah terjadi sejak era perkembangan masyarakat internasional tradisional sampai dengan era perkembangan masyarakat modern. ${ }^{1}$

Perang Dunia II telah melahirkan berbagai tindak pidana baru yang merupakan pelanggaran atas perjanjianperjanjian yang telah ditandatangani diantara negara anggota Liga BangsaBangsa. Pelanggaran-pelanggaran tersebut dalam bentuk kekejaman yang tiada taranya serta pelanggaran atas hukum perang yang tiada bandingnya oleh pihak Jerman dan sekutunya, kejadian-kejadian tersebut telah memperkuat kehendak untuk mengajukan kembali gagasan pembentukan suatu Mahkamah Pidana Internasional. Pada tahun 1947 masalah pembentukan Mahkamah Pidana Internasional diserahkan kepada International Law Commission (ILC) yang terdiri dari kelompok ahli hukum terkemuka dari seluruh negara, yang dibentuk oleh Perserikatan BangsaBangsa dan bertugas menyusun suatu kodifikasi hukum internasional.

Bertitik tolak dari pengalamanpengalaman peperangan, maka masyarakat internasional melalui Perserikatan Bangsa-Bangsa telah sepakat dan menempatkan kejahatankejahtan yang dilakukan semasa peperangan sebagai kejahatan yang

${ }^{1}$ Romli Atmasasmita, Pengantar Hukum Pidana Internasional, Refika Aditama, Bandung, 2006, hal.2.

${ }^{2}$ Ibid, hal, 4-5 mengancam dan merugikan serta merusak tatanan kehidupan masyarakat internasional. Beberapa tindak pidana atau kejahatan tersebut di atas, antara lain adalah agresi (agression), kejahatan perang (war crimes), pembasmian etnis tertentu (genocide), pembajakan di laut (piracy), penculikan (kidnapping), dan narkotika (narkotic crimes) sudah termasuk tindak pidana yang merugikan masyarakat internasional. ${ }^{2}$

Antonio Cassese memberikan pengertian Hukum Pidana Internasional sebagai berikut: ${ }^{3}$

"International Criminal Law is a body of International Law designed both to proscribe international crimes and to impose upon states the obligation to prosecute and punish at least some of those crime. It also regulates internasional proceeding for prosecuting and trying persons accused of such crimes."

Dikatakan, bahwa hukum pidana internasional adalah sekumpulan aturan hukum internasional yang melarang kejahatan-kejahatan internasional dan membebankan kewajiban kepada negara-negara untuk menuntut dan menghukum sekurang-kurangnya beberapa bagian dari kejahatankejahatan itu. Di dalamnya juga mengatur prosedur untuk menuntut dan mengadili orang-orang yang dituduh melakukan kejahatan itu.

Dari mengutip pendapat Antonio Cassese ini akhirnya penulis tertarik untuk membuat tulisan dengan judul "Kejahatan-Kejahatan Internasional (Tindak Pidana Internasional) Dan Peranan International Criminal Court

${ }^{3}$ I Made Pasek Diantha, Hukum Pidana Internasional Dalam Dinamika Pengadilan Pidana Internasional, Prenadamedia Group, Jakarta, 2014, hal.1 
(ICC) Dalam Penegakan Hukum Pidana Internasional." Sehingga akhirnya penulis mencoba mengangkat permasalahan sebagai berikut: pertama, apa-apa saja bentuk dari kejahatankejahatan internasional (tindak pidana internasional)? Kedua, sejauhmana peranan International Criminal Court (ICC) dalam penegakan hukum pidana Internasional?

Adapun tujuan penulisan tulisan ini adalah:

1. Untuk mengkaji dan menganalisis lebih dalam apa-apa saja tindak pidana yang bisa dikategorikan sebagai tindak pidana internasional, bagaimana ciri-cirinya, unsurunsurnya serta bentuk-bentuknya.

2. Untuk mendalami kajian lebih dalam bagaimana penanganan tindak pidana internasional yang dilakukan oleh Mahkamah Pidana Internasiona (International Criminal Court/ICC). Dan seberapa jauh peranan ICC dalam penegakan hukum pidana internasional terutama dalam menyelesaikan perkara-perkara yang berkaitan dengan tindak pidana internasional yang notabene tentu saja menyangkut hubungan antar negara.

Kemudian untuk menganalisis permsalahan dalam tulisan ini penulis mencoba pertama, mengkaji hukum internasional terlebih dahulu. Dalam hal ini penulis mencoba melihat pendapat beberapa ahli dalam mendefinisikam hukum internasional, kemudian mengkaji unsur-unsur hukum internasional, sumbersumbernya baru kemudian apa - apa saja yang menjadi subyek hukum internasional.

Kedua, penulis mencoba untuk mendalami lebih dalam lagi tentang Hukum Pidana Internasional. Hukum Pidana Internasional inilah yang nantinya sebagai teori dasar untuk membahas lebih lanjut kejahatankejahatan internasional (tindak pidana internasional). Pada pembahasan kedua ini penulis mencoba melihat bagaimana sejarah dan perkembangan Hukum Pidana internasional, kemudian dilanjutkan dengan pemaparan beberapa pendapat para ahli mengenai pandangan mereka mengenai Hukum Pidana Internasional. Tentu kita juga harus tahu terlebih dahulu apa saja yang menjadi objek dari studi Hukum Pidana Internasional ini. Asasasas Hukum Pidana Internasional juga menjadi kajian penulis dalam membahas Hukum Pidana Internasional.

Ketiga, penulis membahas tentang kejahatan-kejahatan internasional (tindak pidana internasional), dalam hal ini penulis melihat prasyarat sebuah tindak pidana masuk kategori tindak pidana internasional, ciri-ciri tindak pidana internasional dan jenis-jenis tindak pidana internasional tersebut.

Keempat, barulah pada point yang terkahir penulis mencoba menganalisis sejauh mana peranan International Criminal Court/ICC dalam penegakan hukum pidana internasional, penulis mencoba menguraikan tentang apa dan keberadaan ICC, yuridiksinya meliputi apa saja, kemudian penulis menjelaskan prinsip-prinsip dari ICC. Barulah terakhir memaparkan negara- 
negara apa saja yang sudah tergabung dalam Statuta Roma.

Berdasarkan uraian diatas, sangat relevan sekali bagi penulis untuk mengkaji lebih dalam lagi tentang kejahatan-kejahatan internasional (tindak pidana internasional). Karena karya-karya tulis yang menyangkut hubungan antar negara terutama yang menyangkut tentang kejahatankejahatan antar negara perlu disebarluaskan dan disosialisaikan kepada pemerhati hukum, penegak hukum, mahasiswa fakultas hukum dan tentu masyarakat pada umumnya.

\section{PERMASALAHAN}

1. Apa-apa saja bentuk dari kejahatan-kejahatan internasional (tindak pidana internasional)?

2. Sejauhmana peranan International Criminal Court (ICC) dalam penegkan hukum pidana Internasional?

\section{PEMBAHASAN}

\section{A. HUKUM INTERNASIONAL}

Mengenai Hukum Internasional banyak para ahli yang mendefinisikannya;
Menurut

Kusumaatmadja, Mochtar internasional (publik) adalah keseluruhan kaidah-kaidah dan asas-asas hukum yang mengatur hubungan atau persoalan yang melintasi batas negara-negara
4 Baca lebih lanjut Mochtar Kusumaatmadja, Pengantar Hukum Internasional Buku I-Bagian Umum, Bina Cipta, Bandung, 1997, hal 1-3 (hubungan internasional) yang bukan bersifat perdata. Dari pengertian yang diberikan Mochtar Kusumaatmadja tersebut tampak bahwa hu- bungan internasional tidaklah terbatas hubungan yang dilakukan oleh antar negara saja, tetapi dapat dilakukan oleh negara dengan subjek non negara satu sama lain. ${ }^{4}$

Sedangkan menurut Jawahir Thantowi dan Pranoto Iskandar mengartikan hukum internasional seperangkat aturan yang ditujukan dan dibuat oleh negara-negara yang berdaulat secara eksklusif. Dengan mengutip pendapat Lasssa Oppenheim, Jawahir dan Pranoto selanjutnya mengatakan bahwa hukum internasional bukanlah suatu peraturan yang diberlakukan sebagaimana halnya suatu hukum yang dimilki suatu negara. ${ }^{5}$

Starke sendiri memberikan definisi hukum internasional publik sebagai keseluruhan hukum yang terdiri dari prinsipprinsip dan kaidah-kaidah yang mengikat negara-negara untuk mentaatinya dalam hubungan antar negara-negara itu sendiri.

Menurut Starke, hukum internasional meliputi:

1. Kaidah-kaidah hukum yang berkaitan dengan fungsinya lembaga-lembaga atau organisasi-organisasi internasional, hubungan-
${ }^{5}$ Jawahir Thontowi dan Pranoto Iskandar, Hukum Internasional Kontemporer, Refika Aditama, Bandung, 2006 , hal.3 
hubungan mereka satu satu sama lain, dan hubungan mereka dengan negaranegara dan individu-individu.

2. Kaidah-kaidah hukum tertentu yang berkaitan dengan individu-individu dan badan-badan non negara sejauh hak-hak dan kewajiban individu dan badan non negara tersebut penting bagi masyarakat internasional. ${ }^{6}$

Salah satu definisi hukum internasional yang cukup dapat diandalkan adalah definisi dari Charles Cheny Hyde, seperti yang dikutip oleh J.G Starke sebagai berikut: $^{7}$

"International law may be defined a body of law which is composed for its greater part of principles and rules of conduct which states feel themselves bound to observe, and therefore, do commonly observe in their relation with each other, and which includes also:

a) The rules of law relating to the functioning of international institutions of organizations, their relations with each other, and their relations with states and individual , and

b) Certain rules of law relation to individuals and non-states entities so far as the rights or duties for such individuals and non-states entities

${ }^{6}$ Lihat lebih lanjut J.G Starke, Pengantar Hukum Internasional edisi kesepuluh buku I, Sinar Grafika, Jakarta, 1992, hal 1-2

${ }^{7}$ Wayan Parthiana, Pengantar Hukum Internasional, Mandar Maju, Bandung, 1990, hal.3 are the concern of international community".

\section{Sumber - Sumber Hukum Internasional}

Apakah sumber-sumber hukum internasional itu? Adapun sumbersumber hukum internasional adalah sebaga berikut: ${ }^{8}$

1. Perjanjinan Internasional (Treaties)

2. Hukum Kebiasaan Internasional (International Customary Law)

3. Prinsip-prinsip Hukum Umum yang diakui oleh bangsa yang beradab (General Principles Recognized Civilized Nations)

4. Putusan Pengadilan (Yurisprudensi)

5. Karya Hukum (Writing Publicist)

6. Putusan Organisasi Internasinal

\section{Subyek Hukum Internasional:}

Kebanyakan orang menyatakan bahwa negara merupakan subyek hukum internasional yang terutama. Hal ini adalah wajar karena hubungan antar negara identik dengan hubungan internasional dan istilah hubungan antar negara kadangkadang masih banyak yang dipergunakan orang. Tetapi dewasa ini perkembangan hukum

\footnotetext{
${ }^{8}$ Baca lebih lanjut Sefriani, Hukum Internasional Suatu Pengantar, Rajawal Pers, Jakarta, 2009, hal $.26-53$
} 
internasional tidak lagi mendefinisikan negara merupakan satu-satunya subyek hukum internasional yang utama keadaan ini disebabkan oleh berbagai perubahan yang telah terjadi dalam masyarakat internasional dari abad keabad dan karenanya pencerminan masyarakat international dewasa ini. Sehingga subjek hukum internasional terdiri dari: ${ }^{9}$

1. Negara

2. Tahta Suci (Vatican)

3. Palang Merah Internasional

4. Organisasi Internasional

5. Orang perorangan (individu)

6. Pemberontakan dan pihak dalam sengketa (belligerent)

Dari uraian diatas kita dapat menyatakan bahwa pertama, hukum internasional adalah hukum yang berkaitan dengan berfungsinya lembaga atau organisasi internasional dan hubungannya dengan negara, individu, atau diatara mereka sendiri. Kedua, hukum internasional dibentuk oleh negara-negara. Ketiga, kekuatan berlaku hukum internasional dipertahankan oleh masyarakat internasional. ${ }^{10}$

B. HUKUM

PIDANA INTERNASONAL

Istilah Hukum Pidana Internasional atau international criminal law atau international Strafprocessrecht semula diperkenalkan dan dikembangkan oleh pakar-pakar hukum internasional dari Eropa seperti: Friederich Meili pada tahun 1910 (Swiss), Georg Schwarzenberger pada tahun 1950 (Jerman), Gerhard Mueller pada tahun 1965 (Jerman), J.P Froncois pada tahun 1967, Rolling pada tahun 1979 (Belanda), Van Bemmelen pada tahun 1979 (Belanda), kemudian diikuti oleh pakar hukum dari Amerika serikat seperti: Edmund Wise pada tahun 1965 dan Cherif Bassiouni pada tahun 1986 (Amerika Serikat). ${ }^{11}$

Pengembangan Hukum Pidana Internasional sebagai salah satu cabang ilmu hukum dimulai dari pekerjaan oleh Gerhard O.W. Muelller dan Edmund M. Wise yang telah menyusun suatu karya tulis International Criminal Law (1965) dalam rangka proyek dibawah judul, Comparative Law Project dari University New York. Pekerjaan ini kemudian dilanjutkan oleh Bassiouni dan Van. Nanda (1986), yang telah menulis sebuah karya tulis $A$ Treatise on International Criminal Law (1973). ${ }^{12}$

Menurut Pakar Hukum Pidana Internasional Georg Sehwarzenberger (1950) memberikan enam pengertian Hukum Pidana Internasional ini adalah sebagai berikut: ${ }^{13}$

\footnotetext{
${ }^{9}$ Mochtar Kusumaatmadja, Op.Cit, hal 68-80.

${ }^{10}$ Eddy O.S. Hiariej, Pengantar Hukum Pidana

Internasional, Erlangga, Jakarta, 2009, hal. 6
}

\footnotetext{
${ }^{11}$ Romli Atmasasmita, Op.Cit, hal.19.

${ }^{12}$ Ibid, hal.19.

${ }^{13}$ Ibid, hal 21
} 
1. Hukum Pidana Internasional dalam arti lingkup territorial hukum pidana nasional (international criminal law in the meaning of the territorial scope of municipal criminal law)

2. Hukum Pidana Internasional dalam arti aspek internasional yang ditetapkan sebagai ketentuan dalam hukum pidana nasional (international criminal law the meaning of internationally prescribed municipal criminal law)

3. Hukum Pidana Internasional dalam arti kewenangan internasional yang terdapat di dalam hukum pidana nasional (international criminal law in the meaning of internationally authorized municipal criminal law)

4. Hukum Pidana Internasional dalam arti ketentuan hukum pidana nasional yang diakui sebagai hukum yang patut dalam kehidupan masyarakat bangsa yang beradab (international criminal law in the meaning of municipal criminal law common to civilized nations)

5. Hukum Pidana Internasional dalam arti kerjasama internasional dalam mekanisme administrasi peradilan pidana nasional (international criminal law in the meaning of international cooperation in the administration of municipal criminal justice.)

6. Hukum Pidana Internasional dalam arti kata materil (international criminal law in the material sense of the world)

Menurut Rolling (1979: 169), adanya pembedaan antara national criminal law dan international criminal law, dia juga membedakan antara kedua pengertian tersebut dengan istilah supranational criminal law: ${ }^{14}$

National criminal law atau hukum pidana nasional adalah "the law which has developed within the national legal order and which is founded on a national souce of law" (hukum pidana nasional adalah hukum pidana yang berkembang di dalam kerangka orde peraturan perundang-undangan nasional dan dilandaskan pada sumber hukum nasional)

International criminal law atau hukum pidana internasional adalah "the law which determines what national criminal law will apply to offences actually committed if they contain an international element" (hukum pidana internasional adalah hukum yang menentukan hukum pidana nasional yang akan diterapkan terhadap kejahatankejahatan yang nyata-nyata telah dilakukan bila mana terdapat unsur-unsur internasional di dalamnya).

Supranational criminal law atau hukum pidana supranasional atau "the criminal law of the greater community which comprises States and peoples-means the criminal law standards that have been developed in

${ }^{14}$ Ibid, hal.20 
that greater community" (hukum pidana dan masyarakat yang lebih luas besar terdiri dari negara dan rakyat berarti standar hukum pidana yang telah berkembang di dalam kumpulan masyarakat tersebut)

Adapun ruang lingkup pembahasan hukum pidana internasional meliputi tiga objek studi sebagai berikut: ${ }^{15}$

1. Tindak pidana internasional sejarah perkembangan, konsepsi, dan konvensikonvensi internasional yang berkaitan erat dengan tindak pidana internasional

2. Masalah yurisdiksi kriminal atas tindak pidana internasional

3. Prosedur penegakan hukum pidana internasional termasuk masalah perkembangan kerjasama bilateral dan multilateral di dalam mencegah dan memberantas tindak pidana internasional.

4. Instrumen penegakan hukum pidana internasional perkembangan masalah pembentukan Mahkamah Pidana Internasional.

Berbeda dengan asas hukum pada umumnya, sebagian asas hukum dalam hukum pidana dituangkan dalam peraturan konkret. Asas-asas hukum tersebut biasanya merupakan umum dalam KUHP masing-masing

${ }^{15} \mathrm{Ibid}$, hal.34-35

${ }^{16}$ Untuk memahami lebih dalam mengenai asas-asas hukum pidana internasional baik itu bersumber dari hukum internasional maupun dari hukum nasional negara. Oleh karena itu, selain berasal dari asas-asas hukum internasional, asas-asas dalam hukum pidana internasional juga berasal dari asasasas hukum pidana nasional. Asas-asas hukum pidana internasional tersebut adalah: ${ }^{16}$

\section{Asas Hukum Pidana Internasional yang bersumber dari Hukum Nasional}

Asas hukum pidana internasional yang bersumber dari hukum internasional secara garis besar dibedakan ke dalam asas umum dan asas khusus.

Adapun asas hukum pidana internasional yang berasal dari hukum internasional yang umum sifatnya adalah:

a. Asas Pacta Sunt Servanda

Yang mengandung arti bahwa perjanjian yang dibuat mengikat para pihak ibarat undang - undang. Bila dihubungkan dengan sumber hukum pidana internasional, dapatlah dipahami bahwa perjanjian internasional menempati urutan teratas dalam hirarki sumber hukum pidana internasional.

b. Asas itikad baik atau good faith (Inggris) atau geode trouw (Belanda)

Asas ini merupakan salah satu prinsip yang fundamental dalam hukum internasional yang menyatakan bahwa semua kewajiban yang

baca lebih lanjut Eddy O.S. Hiariej, Pengantar Hukum Pidana Internasional, Erlangga, Jakarta, 2009, hal.2442 
diembani oleh hukum internasional harus dilakukan dengan sebaik-baiknya.

c. Asas civitas maxima

Asas ini mengandung arti bahwa ada sistem hukum universal yang dianut oleh semua bangsa di dunia dan harus dihormati serta dilaksanakan.

d. Asas timbal balik/ asas resiprokal

Asas resiprokal mengandung arti bahwa jika suatu negara menginginkan suatu perlakuan yang baik dari negara lain, maka negara yang bersangkutan tersebut juga harus memberikan perlakuan yang baik juga terhadap negara.

Sedangkan asas hukum pidana internasional yang berasal dari hukum internasional yang khusus sifatnya adalah:

a. Aut dedere aut punere

Bahwa pelaku kejahatan internasional diadili menurut hukum ditempat ia melakukan kejahatan. Dengan kata lain, pelaku kejahatan internasional diadili sesuai dengan locus delicti.

b. Aut dedere aut judicare

Asas ini berarti bahwa setiap negara berkewajiban menuntut dan mengadili pelaku kejahatan internasional serta berkewajiban melakukan kerjasama dengan negara lain dalam rangka menahan, menuntut, mengadili pelaku kejahatan internasional.

c. Par in parem in hebet imperium

Bahwa kepala negara tidak dapat dihukum dengan menggunakan hukum negara lain. Asas ini merupakan hak impunitas atau kekebalan dari seorang kepala negara asing dalam hubungan internasional.

2. Asas Hukum Pidana Internasional yang bersumber dari Hukum Pidana Nasional

\section{a. Asas Legalitas}

Bahwa tidak ada yang dapat dipidana berdasarkan hukum yang telah ditetapkan dan diundangkan sebelum delik tersebut diterapkan secara legal. Asas legalitas ini kemudian tercantum dalam KUHP berbagai negara di dunia.

\section{b. Asas Territorial}

Asas ini diartikan bahwa perundang-undangan hukum pidana suatu negara berlaku bagi semua orang yang melakukan perbuatan pidana di negara tersebut baik oleh warga negara itu sendiri maupun warga negara asing.

c. Asas Ne Bis In Idem atau principle of double jeopardy

Prinsip ini menyatakan seseorang tidak dapat dituntut lebih dari satu kali di depan 
pengadilan atas perkara yang sama. Asas ini bertujuan untuk menjamin kepastian hukum dan melindungi hak asasi manusia. Dalam perkembangan selanjutnya, khususnyaa yang berkaitan dengan kejahatan-kejahatan serius terhadap komunitas masyarakat internasional, asas ne bis in idem ini dapat disesuaikan.

\section{d. Asas-asas Ekstradisi}

Dalam penegakan hukum pidana internasional, terkadang pelaku kejahatan yang akan diproses, diadili, atau dieksekusi tidak berada di wilayah negara yang akan melakukan proses tersebut, tetapi berada di wilayah lain. Jika terjadi demikian maka ektradisi tidak dapat dihindari. Ekstradisi diartikan sebagai penyerahan seseorang tersangka atau terdakwa atau terpidana oleh negara ditempat mana orang tersebut berada kepada negara yang hendak mengadili orang yang diminta atau melaksanakan putusan pengadilan negara dari negara yang diminta. Sedangkan ektradisi internasional adalah permintaan pemerintah suatu negara terhadap negara lain. Ketentuan perihal ekstradisi biasanya diatur dalam undangundang masing-masing negara. Undang-undang tersebut kemudian ditindak lanjuti dengan perjanjian bilateral antara satu negara dengan negara lainnya.

\section{KEJAHATAN-KEJAHATAN INTERNASIONAL (TINDAK PIDANA INTERNASIONAL)}

Sebelum membahas lebih dalam mengenai tindak pidana internasional, perlu diketahui lebih dahulu definisi tindak pidana internasional. Definisi tindak pidana internasional dapat ditemukan dalam putusan peradilan tindak pidana Perang di Amerika dalam kasus Hostages yang menyatakan sebagai berikut:

"An international crimes is such an act universally recognized as a criminal which is considered a grave matter of international concern and for some valid reason cannot be left within the exclusive jurisdiction of the state, that would have control over it under normal circumstances."

Dari uraian definisi tersebut dapat disimpulkan bahwa tindak pidana internasional adalah suatu tindakan yang secara universal diakui sebagai suatu tindak pidana. Pengakuan secara internasional ini disebabkan karena tindak pidana tersebut merupakan persoalan yang sangat besar dan menjadi perhatian masyarakat internasional. Dengan demikian, terhadap tindak pidana ini tidak hanya tunduk pada yurisdiksi negara tertentu saja, tetapi dapat tunduk pada yurisdiksi semua negara atau 
dapat diterapkan yurisdiksi universal. ${ }^{17}$

Adapun persyaratan tindak pidana internasional adalah: ${ }^{18}$

1. Memiliki

unsur

\section{internasional}

Hal ini dimaksud dengan memilki unsur internasional adalah kejahatan tersebut dapat mengancam, baik langsung maupun tidak langsung, perdamaian dan keamanan umat manusia secara keseluruhan. Selain itu pula kejahatan tersebut diakui sebagai perbuatan yang menggoncangkan hati nurani umat manusia atau melanggar nilai-nilai bersama umat manusia.

2. Memilki unsur transnasional Unsur ini menunjukkan bahwa tindak pidana tersebut mempengaruhi keselamatan umum dan kepentingan ekonomi lebih dari suatu negara. Tindak pidana tersebut biasanya melintasi batas-batas wilayah negara, termasuk melibatkan dan mengakibatkan kepada warganegara lebih dari suatu negara dan menggunakan sarana dan prasarana atau cara-cara yang bersifat lintas negara.

3. Memiliki unsur keharusan.

Unsur ini dimaksudkan bahwa dalam rangka pemberantasan dan penegakan hukum pidana internasional, diperlukan kerjasama internasional. Kerjasama tersebut dikarenakan kejahatan tersebut sudah menjadi dilicto jus gentium yang menjadi perhatian lebih dari suatu negara, bahkan diseluruh masyarakat dunia. Oleh karena itu, terhadap kejahatan tersebut semua negara berhak dan berkewajiban menangkap, menahan, menuntut serta mengadili pelaku kejahatan dimanapun tindak pidana internasional itu dilakukan.

\section{Ciri-Ciri Tindak Pidana International: ${ }^{19}$}

1. Terdapat pengakuan secara eksplisit bahwa suatu tindakan merupakan tindakan pidana, tindak pidana internasional, tindak pidana dibawah hukum internasional.

2. Diakui memilki sifat pidana dengan menetapkan kewajiban untuk melarang dilakukan, mencegah, menuntut, memidana, dan sebagainya.

3. Memberikan sifat pidana pada suatu tindakan

4. Terdapat kewajiban atau hak untuk menuntut

5. Terdapat kewajiban atau hak untuk memidana

17 Oetoeng Wahjoe, Hukum Pidana Internasional Perkembangan Tindak Pidana Internasional dan Proses

${ }^{18}$ Ibid, hal.30-31

Penegakannya, Erlangga, Jakartan, 2011, hal. 27 
6. Terdapat kewajiban atau hak untuk mengekstradisikan

7. Memiliki kewajiban atau hak untuk bekerjasama dalam hal penuntutan dan pemidanaan (termasuk memberikan bantuan hukum dalam acara pidana)

8. Menetapkan dasar-dasar yurisdiksi kriminal (teori prioritas)

9. Mendukung ataau menunjang ditetapkannya pengadilan atau international tribunal

10. Menghindarkan pembelaan dengan alasan perintah atasan.

\section{Jenis-Jenis Tindak Pidana (Kejahatan-Kejahatan Internasional) ${ }^{20}$}

Dilihat dari perkembangan dan asal-usul tindak pidana internasional ini, maka eksistensi tindak pidana internasional dapat dibedakan dalam:

1. Tindak pidana internasional yang berasal dari kebiasaan yang berkembang di dalam praktek hukum internasional

2. Tindak pidana internasional yang berasal dari konvensikonvensi internasional

3. Tindak pidana internasional yang lahir dari sejarah perkembangan konvensi mengenai hak asasi manusia.

Tindak pidana internasional yang berasal dari kebiasaan hukum internasional adalah tindak

${ }^{20}$ Untuk memahami lebih lanjut mengenai jenis-jenis tindak pidana internasional baca Romli pidana pembajakan atau piracy, kejahatana perang atau war crimes dan tindak pidana perbudakan Slavery.

Tindak pidana yang berasal dari konvensi-konvensi internasional ini secara historis dibedakan antara tindak pidana internasional yang ditetapkan di dalam suatu konvensi internasional saja (subject of single convention) dan tindak pidana internasional yang ditetapkan oleh banyak konvensi (subject of multiple convention)

Tindak pidana internasional yang lahir dari sejarah perkembangan konvensi mengenai hak asasi manusi merupakan konsekuensi logis akibat Perang Dunia II yang meliputi bukan hanya korbankorban perang mereka yang termasuk combatant, melainkan juga korban penduduk sipil (non combatant) yang seharusnya dilindungi dalam suatu peperangan. Salah satu dari tindak pidana ini adalah crime of genocide sesuai dengan Deklarasi PBB tanggal 11 Desember 1946 yang menetapkan genocide sebagai kejahatan hukum internasional.

Dalam naskah rancangan ketiga Undang - Undang Pidana Internasional atau The International Criminal Code tahun 1954, telah ditetapkan 13 kejahatan yang dapat dijatuhi pidana berdasarkan hukum internasional sebagai kejahatan terhadap perdamaian dan keamanan seluruh umat manusia,

Atmasasmita, Pengantar Hukum Pidana Internasional, Refika Aditama, Bandung, 2006, hal.40-43 
ketiga belas tindak pidana ini adalah sebagai berikut:

1. Tindakan persiapan untuk agresi dan tindakan agresi

2. Persiapan penggunaan kekuatan bersenjata terhadap negara lain.

3. Mengorganisasi atau memberikan dukungan persenjataan yang ditujukan untuk memasuki suatu wilayah.

4. Memberikan dukungan untuk dilakukannya tindakan terorisme di negara asing.

5. Setiap pelanggaran atas perjanjian pembatasn senjata yang telah disetujui

6. Aneksasi wilayah asing

7. Genocide

8. Pelanggaran atas kebiasaan dan hukum perang

9. Setiap pemufakatan, pembujukan, dan percobaan untuk melakukan tindak pidana tersebut pada butir 8 diatas.

10. Piracy

11. Slavery

12. Apartheid

13. Threat and use of force against internationally protected persons.

Bassiouni (1986: 135) telah menyebutkan terdapat 22 jenis kejahatan internasional yang dipandang memenuhi karakteristik tindak pidana. Ke -22 kejahatan jenis kejahatan internasional dimaksud adalah sebagai berikut:
1. Agression

2. War Crimes

3. Unlawful Use of Weapons

4. Crime Againtst Humanity

5. Genocide

6. Racial Discrimination and Apartheid

7. Slyvery and Ralated Crimes $\mathrm{S}$ Torture

8. Mercenarism

9. Unlawful Human Experimentation

10. Piracy

11. Aircraft Hijacking

12. Threat and Use of Force Againts Internationally Protected person

13. Taking of Civilian Hostages

14. Drug Offenses

15. International Traffic in Obscence Publication

16. Destruction and/or Theft of National Treasures

17. Environmental Protection

18. Theft of Nuclear Materials

19. Unlawful Use of the Mails

20. Interference of the Submarine Cables

21. Falsification and Counterfeiting

22. Bribery of Foreign Public Official.
D. PERANAN INTERNATIONAL CRIMINAL COURT (ICC) DALAM PENEGAKAN HUKUM PIDANA INTERNASIONAL

Mahkamah Pidana Internasional (International Criminal Court /ICC $)^{21}$

${ }^{21}$ Anis Widyawati, Hukum Pidana Internasional, Sinar Grafika, Jakarta, 2014, hal. 150 
Mahkamah Pidana Internasional dalam konteks hukum pidana internasional adalah suatu Badan Peradilan tetap yang dibentuk oleh Perserikatan Bangsa-Bangsa. Mahkamah Pidana Internasional merupakan salah satu instrumen Perserikatan Bangsa-Bangsa untuk menuntut dan mengadili para pelaku tindak pidana atau kejahatan internasional. Mahkamah Pidana Internasional didirikan berdasarkan Statuta Roma tahun 1998 (Statute of Rome 1998) yang merupakan hasil konferensi diplomatik yang berlangsung di Roma pada tanggal 15 - 17 Juli 1998. Dalam konferensi tersebut telah dihadiri oleh perwakilan masing-masing negara anggota Perserikatan Bangsa-Bangsa di dunia ataupun utusan-utusan dari organisasi pemerintah maupun organisasi non pemerintah. Setelah diatur didalam Statuta Roma tahun 1998 dan mulai diberlakukan ketentuan didalamnya, Mahkamah Pidana Internasional secara sah telah berdiri sebagai suatu badan peradilan internasional yang bersifat permanen (tetap) dengan tugas, fungsi serta kewenangankewenangan yang dimilikinya. Mahkamah Pidana Internasional (International Criminal Court) berkedudukan di Den Haag, Belanda. Keberadaan Mahkamah Pidana
Internasional sebagai badan
peradilan internasional yang
permanen. Mahkamah ini juga
memiliki karakter hukum
internasional (International legal personality), artinya Mahkamah Pidana Internasional sebagai subjek hukum internasional dengan kemampuan yang dimilikinya, serta terdapat hakhak dan kewajiban-kewajiban berdasarkan hukum internasional. Selain memiliki karakter hukum internasional, Mahkamah Pidana Internasional juga memiliki karakter hukum nasional (National Legal Personality), yang juga berarti sebagai subjek hukum nasional bagi negara-negara peserta ataupun bukan negara peserta (Pasal 4 ayat (2) Statuta Roma tahun 1998).

Kedudukan Mahkamah Pidana Internasional dalam kaitannya dengan Perserikatan BangsaBangsa, karena terbentuknya mahkamah ini tidak bisa terlepas dari prakarsa PBB melalui majelis umum dengan peranan oleh Komisi Hukum Internasional. Mahkamah ini tidak berada di bawah atau sebagai bagian (bagian utama, bagian subsider ataupun bagian khusus) dari PBB, sehingga dapat dikatakan bahwa mahkamah berada di luar sistem PBB dengan kedudukannya sejajar atau setara dengan PBB. Hal ini berdasarkan perjanjian antara mahkamah dan PBB yang tertuang di dalam Pasal 2 Statuta Roma tahun 1998. 


\section{Yurisdiksi Mahkamah Pidana Internasional ${ }^{22}$}

Yuridiksi merupakan kewenangan dalam bertindak berdasarkan ketentuan yang berlaku mengenai tugas, fungsi dan tujuannya. Seperti yurisdiksi-yurisdiksi badan peradilan yang lain, misalnya : Mahkamah Nuremberg 1945, Mahkamah Tokyo 1946, Mahkamah Bekas Yugoslavia 1993, dan Mahkamah Rwanda 1994, keberadaaan Mahkamah Pidana Internasional (International Criminal Court) juga memiliki yurisdiksi, yang diantaranya adalah yurisdiksi personal, yurisdiksi territorial, yurisdiksi temporal, serta yurisdiksi kriminal. Adapun penjelasanpenjelasan mengenai yurisdiksi tersebut adalah sebagai berikut :

\section{a. Yurisdiksi Personal}

Adalah kewenangan yang dimiliki oleh mahkamah untuk mengadili para pelaku kejahatan atau tindak pidana yang berupa orang-orang atau individu-individu yang harus bertanggung jawab atas kejahatan yang dilakukan sebagaimana telah ditentukan didalam Statuta Roma tahun 1998 (Pasal 25 ayat (1), sehingga dalam hal ini, negara bukan merupakan yurisdiksi personal bagi mahkamah ataupun subjek hukum internasional lainnya kecuali individu. Hal yang khusus dalam yurisdiksi personal mahkamah, yaitu mengenai pelaku kejahatan internasional yang usianya kurang dari 18 tahun, maka mahkamah tidak mempunyai wewenang untuk mengadilinya dihadapan persidangan mahkamah, sehingga dapat dimintakan pertanggungjawabannya berdasarkan hukum nasional negara-negara yang bersangkutan (Pasal 26) Statuta Roma tahun 1998.

\section{b. Yurisdiksi Territorial}

Adalah kewenangan mahkamah dalam menjalankan tugas dan fungsi sebagai badan peradilan internasional berdasarkan lokasi atau wilayah hukum atas perbuatan kejahatan internasional itu terjadi. Pada dasarnya yurisdiksi ini berlaku di wilayah negara-negara peserta dalam Statuta Roma tahun 1998 yang apabila terjadi kejahatan lintas batas territorial negara. Akan tetapi dalam hubungannya terhadap negaranegara yang menolak atau tidak menjadi anggota dalam Statute Roma tahun 1998 (tidak ikut meratifikasi isi dari dari Statute Roma tahun 1998), mahkamah tidak dapat menerapkan yuridiksinya terhadap kejahatan yang terjadi di wilayah negara tersebut. Maka dengan demikian para pelaku kejahatan berda di luar jangkauan yurisdiksi mahkamah yang juga tidak

${ }^{22}$ Ibid, hal.151-153 
mendapat kekebalan

(imunitas) dari mahkamah.

\section{c. Yurisdiksi Temporal}

Adalah kewenangan mahkamah sebagaimana diatur didalam Pasal 11 ayat (1) dan (2) Statuta Roma tahun 1998 yang berbunyi: mahkamah hanya memiliki yurisdiksi atas kejahatan yang dilakukan setelah mulai berlakunya statuta ini. Mahkamah tidak memiliki yurisdiksi atas kejahatan yang terjadi sebelumnya, hal ini sesuai dengan salah satu asas hukum pidana internasional, yaitu asas non retroaktif nonretroactive), hal tersebut berdasarkan pada Pasal 24 ayat (1) Statuta Roma tahun 1998.

Mengenai yurisdiksi temporal yang ada pada mahkamah, bahwa tidak memberlakukan asas daluarsa (lapse of time) atas keempat jenis kejahatan yang tunduk pada yurisdiksi sebagaimana tercantum didalam Statuta Roma tahun 1998, yaitu kejahatan genosida, kejahatan terhadap kemanusiaan, kejahatan perang, kejahatan agresi. Hal ini sesuai dengan Pasal 29 Statuta Roma tahun 1998 yang menyatakan bahwa tidak ada satu atau lebih kejahatan dalam yurisdiksi mahkamah yang tunduk pada pembatasan waktu untuk melakukan penuntutan terhadap pelaku kejahatan tersebut.

\section{d. Yurisdiksi Kriminal}

Adalah yurisdiksi yang dimiliki oleh mahkamah dalam menjalankan tugasnya untuk mengadili kejahatan-kejahatan interansional yang termasuk atau diatur didalam Statuta Roma tahun 1998. Dalam yurisdiksi kriminal mahkamah telah diatur dalam Pasal 5 Statuta Roma tahun 1998 yang menyatakan kejahatan dalam yurisdiksi mahkamah, antara lain sebagai berikut :

1) Kejahatan genosida (the crime of genocide)

2) Kejahatan terhadap kemanusiaan (crimes against humanity)

3) Kejahatan perang (war crimes)

4) Kejahatan agresi (the crimes of aggression)

Dari masing - masing jenis kejahatan - kejahatan internasional tersebut diatas, didalam Statuta juga menjelaskan secara rinci mengenai definisi ataupun arti mengenai kejahatan yang dimaksud, seperti dalam Pasal 9 Statuta Roma tahun 1998, menerangkan tentang perlunya dirumuskan secara lebih rinci mengenai unsurunsur masing-masing kejahatan (elements of crimes) dalam membantu untuk menafsirkan atau menerapkan ketentuan terkait pasal yang menunjukkan jenis kejahatan yang dimaksud didalam Statuta Roma tahun 1998. 
Prinsip - Prinsip Dasar

Mahkamah Pidana

\section{Internasional $^{23}$}

Dalam pembahasan mengenai prinsip - prinsip dasar pembentukan Mahkamah Pidana Internasional merupakan landasan yang dijadikan dalam menjalankan tugas dan fungsi dari Mahkamah Pidana Internasional itu sendiri. Menurut Boer Mauna (2005: 297-301) dalam bukunya Hukum Internasional; Pengertian, Peranan, dan Fungsi Dalam Era Dinamika Global memberikan beberapa prinsip dasar yang terdapat dalam Mahkamah Pidana Internasional, antara lain sebagai berikut:

\section{a. Prinsip Komplementer}

Prinsip ini dijelaskan di dalam Mukadimah Statuta Roma tahun 1998, bahwa maksud dari prinsip ini adalah Mahkamah Pidana Internasional merupakan pelengkap dari yurisdiksi pidana nasional. Pasal 1 Statuta Roma tahun 1998 memberikan penjelasan mengenai prinsip komplementer

(Complementary Principle).

Berdasarkan hal ini, merupakan pengakuan terhadap prinsip kedaulatan negara dan harapan masyarakat internasional agar sistem hukum nasional memuat pengaturan hukum untuk mengadili dan menghukum tindak pidana yang menjadi keprihatinan dan kesengsaraan dunia. Sehingga dengan terbentuknya Mahkamah Pidana Internasional tidak bermaksud untuk menggantikan

keberadaannya peranan yurisdiksi nasional yang berlaku di setiap negara.

\section{b. Prinsip Penerimaan}

Merupakan prinsip yang dimiliki oleh mahkamah dalam mengadili suatu perkara di bawah ruang tetap admissibility (masalah penerimaan perkara) yang tercantum di dalam Pasal 17 Statuta Roma tahun 1998. Hal tersebut merujuk pada hubungan antara sistem hukum nasional dan Mahkamah Pidana Internasional dalam menentukan suatu kasus dinyatakan tidak dapat diterima apabila:

1) Perkaranya sedang diperiksa dan diadili oleh negara setempat kecuali negara tersebut tidak mau (unwilling) atau tidak mampu (unable) secara sungguh-sungguh untuk melaksanakan penyidikan atau penuntutan;

2) Perkaranya telah diselidiki oleh negara setempat dan negara tersebut memutuskan untuk tidak melakukan penuntutan terhadap orang yang

${ }^{23}$ Ibid, hal.153-157 
bersangkutan, kecuali jika keputusan itu sebagai akibat dari ketidakmauan (unwilling) atau ketidakmampuan (unable) negara itu untuk sungguhsungguh melakukan penuntutan'

3) Orang yang bersangkutan telah diadili untuk perbuatan yang sama dengan perbuatan yang menjadi dasar tuntutan mahkamah pidana internasional seperti yang disebutkan didalam Pasal 20 ayat (3) Statuta Roma tahun 1998;

4) Kasusnya tidak cukup berat untuk memerlukan tindakan lebih lanjut dari Mahkamah Pidana Internasional.

c. Prinsip Otomatis (Automatic Principle)

Menurut prinsip ini pelaksanaan yurisdiksi mahkamah atas dasar tindakan tindakan pidana yang tercantum dalam Statuta Roma tahun 1998 dengan tidak memerlukan persetujuan dari negaranegara pihak yang bersangkutan. Semua negara secara langsung (otomatis) menerima yurisdiksi mahkamah atas semua kejahatan yang menjadi yurisdiksi dari mahkamah, yang demikian itu terdapat dalam paragraph 12 ayat (1) Statuta Roma tahun 1998. Sedangkan dalam Pasal 12 ayat (2) Statuta Roma tahun 1998 menjelaskan bahwa mahkamah dapat menjalankan yurisdiksinya jika kejahatan terjadi di wilayah negara pihak-pihak dan orang yang melakukan kejahatan tersebut adalah warga negara dari engara anggota Statuta tersebut. Kemudian bagi negara bukan menjadi anggota dari Statuta ini maka negara tersebut melalui suatu pernyataan dapat menerima pelaksaaan yurisdiksi mahkamah atas tindak pidana seperti yang diatur dalam Pasal 12 ayat (3) Statuta Roma tahun 1998.

\section{d. Prinsip Ratio Temporis} (Yurisdiksi Temporal)

Maksud dari prinsip ini terkait waktu berlakunya Statuta Roma tahun 1998 tidak berlaku bagi kejahatan yang terjadi sebelum adanya Statuta ini. Bagi negaranegara yang menjadi anggota Statuta Roma tahun 1998 dinyatakan telah berlaku, mahkamah mempunyai yurisdiksi atas kejahatankejahatan yang dilakukan setelah berlakunya statuta bagi negara-negara anggota tersebut. Sebagai contoh, Negara Colombia meratifikasi Statuta Roma tahun 1998 pada tanggal 1 November 2000, sedangkan statuta tersebut mulai berlaku semenjak tanggal 1 Juli 2000. Oleh karena itu, mahkamah tidak boleh menuntut 
kejahatan-kejahatan yang terjadi di negara Colombia antara tanggal 1 Juli sampai dengan 1 November 2000. $\mathrm{Hal}$ ini ditegaskan dalam Pasal 24 Statuta Roma tahun 1998, bahwa seseorang tidak bertanggung jawab secara pidana untuk suatu tindakan sebelum berlakunya Statuta Roma tahun 1998 bagi negara yang bersangkutan. Inilah yang dinamakan prinsip non retroactive ratio personal.

e. Prinsip Nullum Crimen Sine Lege

Maksud dari prinsip ini terdapat didalam Pasal 22 Statuta Roma tahun 1998 dibawah asas-asas umum dalam hukum pidana. Dijelaskan bahwa tidak seorangpun dapat bertanggungjawab secara pidana berdasarkan statuta, kecuali tindakan tersebut waktu dilakukan merupakan suatu tindak pidana yang berada dalam yurisdiksi dan kewenangan mahkamah. Selanjutnya prinsip nullum crimen sine lege diperjelas oleh Pasal 23 Statuta Roma tahun 1998 bahwa seseorang yang telah didakwa mahkamah hanya dapat dijatuhi pidana sesuai dengan ketentuan yang diatur dalam Statuta Roma tahun 1998.

\section{f. Prinsip Nebis in Idem}

Prinsip ini terdapat dalam Pasal 20 Statuta Roma tahun 1998 bahwa seseorang tidak dapat dituntut lagi oleh mahkamah atas tindak pidana yang sama yang telah diputuskan atau dibebaskan oleh mahkamah. Oleh karena itu, seseorang tidak dapat diadili lagi oleh mahkamah atau pengadilan lain untuk suatu tindak pidana yang sama sebagaimana disebutkan dalam Pasal 5 Statuta Roma tahun 1998, dimana tindak pidana itu telah diputuskan dengan putusan pidana atau dibebaskan oleh mahkamah.

g. Prinsip Ratio Loctie (yurisdiksi Teritorial)

Merupakan prinsip bagi mahkamah yang memiliki yurisdiksi atas kejahatankejahatan yang dilakukan di wilayah negara- negara anggota tanpa memandang kewarganegaraan dari pelaku. Prinsip umum ini diatur didalam Pasal 12 ayat (2) butir (a) Statuta Roma tahun 1998. Mahkamah mempunyai yurisdiksi atas kejahatan-kejahatan yang menerima yurisdiksinya atas ad hoc dan wilayah yang ditunjuk oleh Dewan Keamanan.

h. Prinsip Tanggung Jawab Pidana secara Individual Menurut Pasal 25 Statuta Roma tahun 1998, mahkamah mempunyai yurisdiksi atas individu sebagai "natural person". Seseorang yang melakukan 
tindak pidana di wilayah yurisdiksi mahkamah bertanggung jawab secara pribadi dan dapat dihukum sesuai isi dalam Statuta Roma tahun 1998. Ketentuan ini merupakan pencerminan untuk mengadili dan menghukum individu dan bukan negara. Kejahatan terhadap hukum internasional dilakukan oleh individu dan bukan entitas yang abstrak. Hanya dengan menghukum individu yang melakukan kejahatan, hukum internasional dapat ditegakkan seperti kasus yang terjadi dan diadili oleh Pengadilan Nuremberg tahun 1946.

\section{i. Prinsip Praduga tak bersalah} (Presumption of Innocence)

Maksud dari prinsip ini adalah bahwa setiap orang harus dianggap tidak bersalah sampai dengan terdapatnya putusan dari pengadilan bawah mereka terbukti dan dinyatakan bersalah. Diatur dalam Pasal 66 Statuta Roma tahun 1998 yang menyatakan setiap orang dianggap tidak bersalah sampai terbukti bersalah dihadapan mahkamah sesuai dengan hukum yang berlaku. Beban pembuktian dan tanggung jawab terdapat kepada Jaksa Penuntutan yang akan membuktikan terdakwa bersalah.

\section{j. Prinsip Hak Veto Dewan Keamanan untuk menghentikan Penuntutan}

Merupakan hak yang dimiliki oleh Dewan Keamanan (Security Council) PBB untuk dapat mencegah mahkamah dalam melaksanakan yurisdiksinya sesuai dengan Pasal 16 Piagam PBB. Menurut pasal tersebut bahwa tidak ada penyidikan atau penuntutan yang dapat dimulai atau dilaksanakan sesuai statuta untuk jangka waktu 12 bulan setelah Dewan Keamanan PBB dalam resolusinya yang dibuat menurut $\mathrm{Bab}$ VII Piagam, meminta mahkamah untuk menangguhkan penyidikan atau penuntutan. Permintaan tersebut dapat diperbaharui oleh Dewan dalam keadaan yang sama. Inilah yang dinamakan prinsip defferal atau penangguhan yang dapat diperbaharui. Kebijaksanaan ini dalam praktiknya bisa saja terjadi berlangsung terusmenerus. Namun, meskipun permintaan defferal oleh Dewan Keamanan PBB dapat diperbaharui atau diulangi kembali, terdapat kemungkinan terjadinya perubahan-perubahan politik dan berkurangnya unaminitas atau keseragaman pendapat dikalangan negara anggota tetap yang mempunyai hak veto. Sehingga hal tersebut tidak memungkinkan tercapainya 
lagi konsensus untuk mengajukan defferal kembali.

\section{Struktur Organisasi Mahkamah Pidana Internasional ${ }^{24}$}

Mahkamah Pidana Internasional merupakan badan peradilan internasional menjalankan tugastugasnya pada lingkup kejahatankejahatan internasional, maka tentunya struktur organisasi yang dimilikinya berbeda dengan mahkamah sebelumnya ataupun badan peradilan pada umumnya. Struktur bagian dalam Mahkamah Pidana Internasional (International Criminal Court) telah diatur dalam Pasal 34 Statuta Roma tahun 1998, yang terdiri dari :

a. Kepresidenan (Presidency);

b. Divisi Banding, Divisi Peradilan, dan Divisi Praperadilan (an Appeals Division, a Trial Division and a Pre Trial Division);

c. Kantor Jaksa Penuntut (The Office of the Prosecutor);

d. Kepaniteraan (The Registery) Bagian Mahkamah dari

Kepresidenan (The Presidency) mempunyai peran yang penuh dalam menjalankan tugas yang berkaitan dengan perkara dalam mahkamah. Pasal 35 ayat (2), menerangkan bahwa the judges composing the presidency shall serve on a full time basis as soon as they elected, yang artinya bahwa para hakim (seluruh hakim mahkamah) harus menjalankan tugasnya atau bekerja full time setelah terpilih sebagai hakim mahkamah. Komposisi hakim mahkamah terdapat 18 hakim yang dipilih dari negara anggota (peratifikasi) dengan masa tugas atau jabatan selama 9 (Sembilan) tahun.

Bagian mahkamah dari kepresidenan (the presidency) mempunyai peran yang penuh dalam menjalankan tugas yang berkaitan dengan perkara dalam mahkamah. Pasal 35 ayat (2), menerangkan bahwa the judges composing the presidency shall serve on a full-time basis as soon as they elected, yang artinya bahwa para hakim (seluruh hakim mahkamah) harus menjalankan tugasnya atau bekerja full time setelah terpilih sebagai hakim mahkamah. Komposisi hakim mahkamah terdapat 18 hakim yang dipilih dari negara anggota (peratifikasi) dengan masa tugas atau jabatan selama 9 (sembilan) tahun.

Bagian mahkamah yang selanjutnya adalah divisi-divisi dalam Mahkamah Pidana Internasional. Divisi ini terbentuk setelah terpilih para hakim mahkamah yang menjalankan tugas dan tanggung jawab jawabnya. Berdasarkan pada Pasal 39 ayat (1) Statuta Roma tahun 1998 yang berbunyi:

"As soon possible after the election of the judges, the Court shall Bagianize itself into the divisions specified in article 34, paragraph (b). the Appeals Divisions shall be composed of the president and four other judges, she

${ }^{24}$ Ibid, hal. $157-158$ 
trial divisions of not less than six judges and the Pre-Trial division of not less than six judges. The assignment of judges to division shall be based on the nature of functions to be performed by each division and the qualifications and experience of the judges elected to the Court, in such a way that each division shall contain an appropriate combination of expertise in criminal law and procedure in international law. The trial and Pre-Trial Divisions shall be composed predominantly of judges with criminal trial experience".

Arti dari penjelasan pasal di atas mengenai susunan divisi-divisi mahkamah adalah sebagai berikut:

a) Divisi Banding yang terdiri dari seorang Ketua (Presiden) dengan empat orang hakim

b) Divisi Peradilan yang terdiri dari tidak kurang dari enam orang hakim

c) Divisi Pra-Peradilan yang terdiri dari tidak kurang dari enam hakim.

Bagian mahkamah berikutnya, yaitu Kantor Jaksa Penuntut (the Office of the Prosecutor), keberadaan bagian ini terpisah atau berdiri sendiri dari amhkamah karena sifatnya yang independen dan mandiri dalam menjalankan tugas-tugasnya. Unsur jaksa diambil dari negara peserta dengan masa jabatan 9 tahun dan tidak dapat diangkat kembali. Jaksa dapat bertindak atas penyerahan dari negara atau melalui Dewan Keamanan PBB, dan dapat pula berinisiatif melakukan penyelidikan atas kehendak sendiri (proprio motu) atas dasar informasi dan dokumen penyerahan perkara tentang kejahatan dalam yurisdiksi Mahkamah Pidana Internasional.

Struktur bagian mahkamah selanjutnya, yaitu Kepaniteraan (the registery), tugas utama yang dilakukan kepaniteraan di antaranya melaksanakan tugasnya dalam bidang nonyudisial, administratif, dan pelayanan di bawah Presiden Mahkamah. Yang dapat menjadi anggota kepaniteraan mahkamah hanya negara peserta yang mendapat rekomendasi dari majelis. Panitera bekerja secara penuh waktu dalam masa jabatan selama 5 (lima) tahun dan kemudian dapat dipilih kembali dengan kesempatan satu kali saja. Dalam membantu tugasnya, maka panitera membentuk beberapa unit di dalam Bagian Kepaniteraan itu sendiri, seperti unit korban dan unit saksi, hal tersebut berguna dalam membantu mahkamah (dalam hal ini) hakim untuk melaksanakan tugasnya, yaitu mengadili para pelaku kejahatan internasional.

Ketentuan dari Statuta Roma tahun 1998 mempunyai arti dan maksud yang berkaitan dengan tidak dapat diterimanya suatu perkara, yakni sebagai berikut: ${ }^{25}$

${ }^{25}$ Ibid, hal. 160-161 
1. Suatu perkara tidak dapat diterima untuk ditangani oleh Mahkamah

Pidana Internasional (International Criminal Court) apabila :

a) Kasusnya sedang disidik atau dituntut oleh suatu negara yang mempunyai yurisdiksi atas perkara tersebut, kecuali bila negara tersebut tidak bersedia atau tidak dapat melakukan penyelidikan dan penuntutan;

b) Kasusnya telah diselidiki oleh suatu negara yang mempunyai yurisdiksi atas perkara tersebut dan negara itu telah memutuskan untuk tidak menuntut orang yang bersangkutan, kecuali apabila keputusan itu diambil karena ketidakmauan (unwilling) atau ketidakmampuan (unable) untuk melakukan penuntutan;

c) Tersangka telah diadili atas perbuatan yang diadukan atau pengadilan tidak berwenang mengadili berdasarkan Pasal 20 ayat (3) Statuta Roma tahun 1998;

d) Kasusnya tidak cukup berat untuk diperiksa dan diadili oleh Pengadilan Pidana Internasional (International Criminal Court).

2. Dalam rangka menentukan ketidaksediaan Negara tertentu untuk menuntut yang bersalah, Mahkamah Pidana Internasional (International Criminal Court) mempertimbangkan dengan mengacu pada prinsip-prinsip hukum internasional, yaitu mengenai hal-hal sebagai berikut:

a) Tampak adanya upaya hukum dan sikap nasional suatu negara untuk "melindungi" atau menutupi perbuatan si pelaku dari tanggung jawab yurisdiksi Mahkamah Pidana Internasional (International Criminal Court) sebagaimana diatur dalam Pasal 15 Statuta Roma tahun 1998.

b) Tindakan "penangguhan" yang tidak dapat dibenarkan yang bersifat "tidak rela" membawa orang yang bersalah ke pengadilan untuk diadili.

c) Tidak adanya upaya hukum yang mencerminkan tindakan yang tidak sesuai dengan maksud untuk membawa orang yang bersalah ke Pengadilan untuk diadili.

3. Untuk menentukan "ketidakmampuan" (unable) dalam suatu kasus tertentu, Mahkamah Pidana Internasional (International Criminal Court) mempertimbangkan apakah disebabkan kekurangan system nasionalnya secara 
menyeluruh / sebagian besar, sehingga negara tersebut tidak mampu menghadirkan tersangka, tidak dapat menunjukkan bukti dan kesaksiannya yang diperlukan atau ada upaya hukum kea rah pemeriksaan di pengadilan.

Dalam hal ini jenis hukuman yang dapat diberikan oleh Mahkamah kepada terdakwa berupa (Parthiana,2006: 246-247): ${ }^{26}$

a) Hukuman penjara untuk selama jangka waktu tertentu tetapi tidak boleh melebihi dari maksimum 30 tahun;

b) Hukuman penjara untuk seumur hidup, apabila hal ini dibenarkan atas dasar pertimbangan mengenai beratnya kejahatan yang dilakukan dan keadaankeadaan individual dari terdakwa sebagai orang yang akan dijatuhi hukuman seumur hidup.

c) Hukuman berupa denda, denda ini ditetapkan berdasarkan kriteria sebagaimana ditentukan dalam hukum acaradan pembuktian;

d) Penebusan hasil, harta kekayaan dan asset yang baik secara langsung maupun tidak langsung berkaitan dengan kejahatan tersebut, tanpa merugikan hak-hak pihak ketiga yang ber'itikad baik.
Dalam Statuta Roma Mahkamah Pidana Internasional tahun 1998, disebutkan bahwa: ${ }^{27}$

1) Suatu negara yang menjadi peserta Statuta ini menerima yurisdiksi pengadilan berkenaan dengan kejahatan yang disebutkan dalam Pasal 5 (kejahatan genosida, kejahatan terhadap kemanusiaan, kejahatan perang, dan kejahatan agresi);

2) Dalam hal Pasal 13, huruf (a) dan (c), pengadilan dapat melaksanakan yurisdiksinya kalau satu atau lebih negara berikut ini adalah peserta statuta atau telah menerima yurisdiksi International Criminal Court (ICC):

3) Kalau penerimaan suatu negara yang bukan peserta dari statuta ini disyaratkan berdasarkan ayat (2), negara tersebut dapat, dengan deklarasi yang disampaikan kepada Panitera International Criminal Court (ICC), menerima pelaksanaan yurisdiksi oleh pengadilan berkenaan dengan sangkaan yang telah dilakukan secepatnya menggelar peradilan (Pasal 12). 
Tabel Daftar Negara

Peratifikasi Statuta Roma 1998

(terhitung sampai tanggal 20 Juni 2013)

\begin{tabular}{|c|c|c|c|}
\hline No & Negara & No & Negara \\
\hline 1 & Afganistan & 62 & Kenya \\
\hline 2 & Albania & 63 & Latvia \\
\hline 3 & Andorra & 64 & Lesotho \\
\hline 4 & Antigua \& Barbuda & 65 & Liberia \\
\hline 5 & Argentina & 66 & Lichenstein \\
\hline 6 & Australia & 67 & Lithuania \\
\hline 7 & Austria & 68 & Luxemboourg \\
\hline 8 & Bangladesh & 69 & Madagascar \\
\hline 9 & Barbados & 70 & Malawi \\
\hline 10 & Belgium & 71 & Maldives \\
\hline 11 & Belize & 72 & Mali \\
\hline 12 & Benin & 73 & Malta \\
\hline 13 & Bolivia & 74 & Marshall Island \\
\hline 14 & Bosnia Herzegovina & 75 & Mauritius \\
\hline 15 & Botswana & 76 & Mexico \\
\hline 16 & Brazil & 77 & Mongolia \\
\hline 17 & Bulgaria & 78 & Montenegro \\
\hline 18 & Burkina Faso & 79 & Namibia \\
\hline 19 & Burundi & 80 & Nauru \\
\hline 20 & Cambodia & 81 & Netherlands \\
\hline 21 & Canada & 82 & New Zealand \\
\hline 22 & Cape Verde & 83 & Niger \\
\hline 23 & $\begin{array}{l}\text { Central African } \\
\text { Republic }\end{array}$ & 84 & Negeria \\
\hline 24 & Chad & 85 & Norway \\
\hline 25 & Chile & 86 & Panama \\
\hline 26 & Colombia & 87 & Paraguay \\
\hline 27 & Comoros & 88 & Peru \\
\hline 28 & Congo & 89 & Philiphines \\
\hline 29 & Cook Island & 90 & Poland \\
\hline 30 & Costa Rica & 91 & Portugal \\
\hline 31 & Cote d'Ivoire & 92 & Republic of Korea \\
\hline 32 & Croatia & 93 & Republic of Moldova \\
\hline 33 & Cyprus & 94 & Romania \\
\hline 34 & Czech Republic & 95 & Saint kitts \& Nevis \\
\hline 35 & Democratic Congo & 96 & Saint Lucia \\
\hline 36 & Denmark & 97 & $\begin{array}{l}\text { Saint Vncent \& } \\
\text { Granadies }\end{array}$ \\
\hline 37 & Djibouti & 98 & Samoa \\
\hline 38 & Dominicia & 99 & San Marino \\
\hline 39 & $\begin{array}{l}\text { Dominicam } \\
\text { Republic }\end{array}$ & 100 & Senegal \\
\hline 40 & Ecuador & 101 & Serbia \\
\hline 41 & Estonia & 102 & Seychelles \\
\hline 42 & Fiji & 103 & Sierra Leone \\
\hline 43 & Finland & 104 & Slovakia \\
\hline 44 & France & 105 & Slovenia \\
\hline 45 & Gabon & 106 & South Africa \\
\hline 46 & Gambia & 107 & Spain \\
\hline 47 & Georgia & 108 & Suriname \\
\hline 48 & Germany & 109 & Sweden \\
\hline 49 & Ghana & 110 & Switzerland \\
\hline 50 & Greece & 111 & Tazikistan \\
\hline 51 & Grenada & 112 & $\begin{array}{l}\text { The Former Yugoslav } \\
\text { Republic of } \\
\text { Macedonia }\end{array}$ \\
\hline 52 & Guatemala & 113 & Timor Leste \\
\hline
\end{tabular}

${ }^{28}$ Lihat lebih lanjut Pasal 126 Statuta Roma.

\begin{tabular}{|c|l|c|l|}
\hline 53 & Guinea & 114 & Trinidad \& Tobago \\
\hline 54 & Guyana & 115 & Tunisia \\
\hline 55 & Honduras & 116 & Uganda \\
\hline 56 & Hungary & 117 & United Kingdom \\
\hline 57 & Iceland & 118 & $\begin{array}{l}\text { United Republic of } \\
\text { Tanzakia }\end{array}$ \\
\hline 58 & Ireland & 119 & Uruguay \\
\hline 59 & Italy & 120 & Vanuatu \\
\hline 60 & Japan & 121 & Venezuela \\
\hline 61 & Jordan & 122 & Zambia \\
\hline
\end{tabular}

Sumber: Dikutip dari International Criminal Court (ICC) dalam buku Tolib Effendi, Hukum Pidana Internasional, Pustaka Yustisia, Yogyakarta, 2014, 242-243

Berdasarkan ketentuan dalam Pasal 126 Statuta Roma 1998, bahwa Statuta Roma mulai berlaku (entry into force) setelah diratifikasi oleh 60 negara. ${ }^{28}$ Pada bulan April 2002, Statuta Roma 1998 dinyatakan berlaku dan ICC mulai berdiri.

Sebagai salah satu instrumen penegak hukum, dalam konteks keadilan ICC memiliki fungsi umum yang ada pada hukum pidana, sebagaimana disampaikan oleh LaFave yang dikutip oleh Arie Siswanto: ${ }^{29}$

a. Retribution, yang mengandung arti bahwa hukum pidana dipergunakan untuk memberikan balasan dan penderitaan yang setimpal bagi pelaku tindak pidana berdasarkan prinsip an eye for an eye.

b. Detterance, yang berarti mencegah orang lain atau pelaku untuk melakukan (lagi) tindak pidana.

${ }^{29}$ Tolib Effendi, Hukum Pidana Internasional, Pustaka Yustisia, Yogyakarta, 2014, hal.244. 
c. Denunciation, yakni menegaskan bahwa tindak pidana yang telah dilakukan oleh pelakunya adalah tindakan salah.

d. Incapacitation, menjaga (melalui lembaga penahanan) supaya pelaku tidak mampu lagi melakukan tindak pidana.

e. Rehabilitation, memperbaiki pelaku tindak pidana.

\section{PENUTUP}

Pada bagian penutup ini penulis mencoba menyimpulkan dari dua permasalahan yang penulis angkat yaitu apa-apa saja bentuk kejahatankejahatan internasional (tindak pidana internasional) serta sejauhmana peranan Mahkamah Pidana Internasional (International Criminal Court/ICC) dalam menangani tindak pidana internasional tersebut. Bahwa kita dapat menyimpulkan bahwa tindak pidana internasional adalah suatu tindakan yang secara universal diakui sebagai suatu tindak pidana.

Pengakuan secara internasional ini disebabkan karena tindak pidana tersebut merupakan persoalan yang sangat besar dan menjadi perhatian masyarakat internasional. Dengan demikian, terhadap tindak pidana ini tidak hanya tunduk pada yurisdiksi negara tertentu saja, tetapi dapat tunduk pada yurisdiksi semua negara atau dapat diterapkan yurisdiksi universal. Tindak pidana internasional ini harus mempunyai persayaratan yaitu: memiliki unsur internasional, memilki unsur transnasional, memiliki unsur keharusan.

\section{Ciri - Ciri Tindak Pidana International:}

1. Terdapat pengakuan secara eksplisit bahwa suatu tindakan merupakan tindakan pidana, tindak pidana internasional, tindak pidana dibawah hukum internasional.

2. Diakui memilki sifat pidana dengan menetapkan kewajiban untuk melarang dilakukan, mencegah, menuntut, memidana, dan sebagainya.

3. Memberikan sifat pidana pada suatu tindakan

4. Terdapat kewajiban atau hak untuk menuntut

5. Terdapat kewajiban atau hak untuk memidana

6. Terdapat kewajiban atau hak untuk mengekstradisikan

7. Memiliki kewajiban atau hak untuk bekerjasama dalam hal penuntutan dan pemidanaan (termasuk memberikan bantuan hukum dalam acara pidana)

8. Menetapkan dasar-dasar yurisdiksi kriminal (teori prioritas)

9. Mendukung ataau menunjang ditetapkannya pengadilan atau international tribunal

10. Menghindarkan pembelaan dengan alasan perintah atasan

\section{Mahkamah Pidana Internasional (International Criminal Court)}

Mahkamah Pidana Internasional dalam konteks hukum pidana internasional adalah suatu Badan Peradilan tetap yang dibentuk oleh Perserikatan Bangsa-Bangsa. Mahkamah Pidana Internasional merupakan salah satu instrumen 
Perserikatan Bangsa-Bangsa untuk menuntut dan mengadili para pelaku tindak pidana atau kejahatan internasional. Mahkamah Pidana Internasional didirikan berdasarkan Statuta Roma tahun 1998 (Statute of Rome 1998) yang merupakan hasil konferensi diplomatik yang berlangsung di Roma pada tanggal 15 - 17 Juli 1998. Dalam konferensi tersebut telah dihadiri oleh perwakilan masing-masing negara anggota Perserikatan Bangsa-Bangsa di dunia ataupun utusan-utusan dari organisasi pemerintah maupun organisasi non pemerintah. Setelah diatur didalam Statuta Roma tahun 1998 dan mulai diberlakukan ketentuan didalamnya, Mahkamah Pidana Internasional secara sah telah berdiri sebagai suatu badan peradilan internasional yang bersifat permanen (tetap) dengan tugas, fungsi serta kewenangankewenangan yang dimilikinya. Mahkamah Pidana Internasional (International Criminal Court) berkedudukan di Den Haag, Belanda.

Mahkamah Internasional sendiri mempunyai prinsip-prinsip dasar yaitu: prinsip komplementer, prinsip penerimaan, prinsip otomatis, prinsip ratio temporis, prinsip nullum crimen sine lege, prinsip nebis in idem, prinsip ratio loctie, prinsip tannggungjawab pidana secara indidual, prinsip praduga tak bersalah, prinsip hak veto Dewan keamanan untuk menghentikan penuntutan.

Adapun yurisdiksi kriminal yang dimiliki oleh mahkamah internasional (internasional criminal court/ICC adalah menjalankan tugasnya untuk mengadili kejahatan-kejahatan interansional yang termasuk atau diatur didalam Statuta Roma tahun 1998. Dalam yurisdiksi kriminal mahkamah telah diatur dalam Pasal 5 Statuta Roma tahun 1998 yang menyatakan kejahatan dalam yurisdiksi mahkamah, antara lain sebagai berikut:

a) Kejahatan genosida (the crime of genocide)

b) Kejahatan terhadap kemanusiaan (crimes against humanity)

c) Kejahatan perang (war crimes)

d) Kejahatan agresi (the crimes of aggression)

Demikianlah uraian penulis tentang kejahatan-kejahatan (tindak pidana internasional) dan peranan Mahkamah Pidana Internasinal (International Criminal Court / ICC) dalam Penegakan Hukum Pidana Internasional. Semoga tulisan ini dapat bermanfaat buat pemerhati hukum, penegak hukum, serta praktisi hukum terutama yang mengkaji di bidang Hukum Pidana Internasional dan semoga dapat bermanfat juga bagi seluruh civitas akademika khususnya di lingkungan Universitas Suryadarma Jakarta. Amin.

\section{DAFTAR PUSTAKA}

Atmasasmita, Romli, Pengantar Hukum Pidana Internasional, Refika Aditama, Bandung, 2006.

Diantha, I Made Pasek, Hukum Pidana Internasional Dalam Dinamika Pengadilan Pidana Internasional, Prenadamedia Group, Jakarta, 2014. 
Effendi, Tolib, Hukum Pidana Internasional, Pustaka Yustisia, Yogyakarta, 2014

Hiariej, Eddy O.S, Pengantar Hukum Pidana Internasional, Erlangga, Jakarta, 2009.

Kusumaatmadja, Mochtar, Pengantar Hukum Internasional, Buku I-Bagian Umum, Bina Cipta, Bandung, 1997.

Parthiana, Wayan, Pengantar Hukum Internasional, Mandar Maju, Bandung, 1990

Sefriani, Hukum Internasional Suatu Pengantar, Rajawali Pers, Jakarta, 2014

Starke, J.G, Pengantar Hukum Internasional Edisi Kesepuluh, Sinar Grafika, Jakarta, 1992.

Thontowi Jawahir dan Iskandar Pranoto, Hukum International Kontemporer, Refika Aditama, Bandung, 2006.

Wahjoe, Oentoeng, Hukum Pidana Internasional Perkembangan Tindak Pidana Internasional dan Proses Penegakannya, Erlangga, Jakarta, 2011

Widyawati, Anis, Hukum Pidana Internasional, Sinar Grafika, Jakarta, 2014

Rome Statute The International Criminal Court, 17 Juli 1998. 